J. Dairy Sci. 92:5917-5927

doi:10.3168/jds.2009-2535

(c) American Dairy Science Association, 2009.

\title{
The effect of bleaching agent on the flavor of liquid whey and whey protein concentrate
}

\author{
A. E. Croissant, ${ }^{*}$ E. J. Kang, ${ }^{*}$ R. E. Campbell, ${ }^{*}$ E. Bastian, $†$ and M. A. Drake ${ }^{* 1}$ \\ *Department of Food, Bioprocessing, and Nutrition Sciences, Southeast Dairy Foods Research Center, North Carolina State University, \\ |Raleigh 27695 \\ †Glanbia Nutritionals, Twin Falls, ID 83301
}

\section{ABSTRACT}

The increasing use and demand for whey protein as an ingredient requires a bland-tasting, neutral-colored final product. The bleaching of colored Cheddar whey is necessary to achieve this goal. Currently, hydrogen peroxide (HP) and benzoyl peroxide (BPO) are utilized for bleaching liquid whey before spray drying. There is no current information on the effect of the bleaching process on the flavor of spray-dried whey protein concentrate (WPC). The objective of this study was to characterize the effect of bleaching on the flavor of liquid and spray-dried Cheddar whey. Cheddar cheeses colored with water-soluble annatto were manufactured in duplicate. Four bleaching treatments (HP, 250 and $500 \mathrm{mg} / \mathrm{kg}$ and BPO, 10 and $20 \mathrm{mg} / \mathrm{kg}$ ) were applied to liquid whey for $1.5 \mathrm{~h}$ at $60^{\circ} \mathrm{C}$ followed by cooling to $5^{\circ} \mathrm{C}$. A control whey with no bleach was also evaluated. Flavor of the liquid wheys was evaluated by sensory and instrumental volatile analysis. One HP treatment and one BPO treatment were subsequently selected and incorporated into liquid whey along with an unbleached control that was processed into spray-dried WPC. These trials were conducted in triplicate. The WPC were evaluated by sensory and instrumental analyses as well as color and proximate analyses. The HP-bleached liquid whey and WPC contained higher concentrations of oxidation reaction products, including the compounds heptanal, hexanal, octanal, and nonanal, compared with unbleached or BPO-bleached liquid whey or WPC. The HP products were higher in overall oxidation products compared with $\mathrm{BPO}$ samples. The HP liquid whey and WPC were higher in fatty and cardboard flavors compared with the control or BPO samples. Hunter CIE Lab color values $\left(\mathrm{L}^{*}, \mathrm{a}^{*}\right.$, $\mathrm{b}^{*}$ ) of WPC powders were distinct on all 3 color scale parameters, with HP-bleached WPC having the highest $\mathrm{L}^{*}$ values. Hydrogen peroxide resulted in a whiter

Received July 1, 2009.

Accepted August 11, 2009.

${ }^{1}$ Corresponding author: maryanne_drake@ncsu.edu
WPC and higher off-flavor intensities; however, there was no difference in norbixin recovery between HP and BPO. These results indicate that the bleaching of liquid whey may affect the flavor of WPC and that the type of bleaching agent used may affect WPC flavor.

Key words: whey protein concentrate, solid-phase microextraction, flavor, bleach

\section{INTRODUCTION}

Liquid whey has transitioned from a byproduct of the cheese industry to a source for high-value ingredients recognized for their nutritional and functional attributes. Liquid whey can be dried or further processed into concentrated whey, whey protein concentrate (WPC; $34-89 \%$ protein), and whey protein isolate (WPI; $>90 \%$ protein) for added value. Whey protein concentrates are being used in an increasing number of food and beverage items. The flavor of whey protein is a concern for the dairy industry (Childs et al., 2007; Drake et al., 2009; Wright et al., 2009). Until recently the stale, objectionable flavor attributed to whey (Morr and Ha, 1991) has limited its use to heavily flavored products. The investigation and source identification of whey product flavors will continue to drive the innovation and development of protein-based products by removing the barriers for use in bland, delicately flavored products. Lipid oxidation products including methyl ketones, aldehydes, and free fatty acids have been identified as primary contributors to off-flavors in whey proteins (Carunchia Whetstine et al., 2005; Wright et al., 2009). Tremendous flavor differences have been documented among commercial WPC (Carunchia Whetstine et al., 2005; Drake et al., 2009; Wright et al., 2009). Factors that may influence the flavor of whey protein products are variability among production plants (Carunchia Whetstine et al., 2003), cheese type, and storage conditions of the product (Drake et al., 2009; Wright et al., 2009). Previous preliminary studies have also suggested that liquid whey process time may play a role in whey protein flavor (Tomaino et al., 2004). 
More than 1.3 billion kilograms of Cheddar cheese was produced in the United States in 2007 (ADPI, 2008). Cheddar cheese whey is the primary source of WPC, which accounted for nearly $15 \%$ of the total dry whey solids produced in 2007 (IDFA, 2008). The combination of consumer demand for yellow Cheddar cheese and ingredient demand for a bland, neutral-color WPC makes bleaching of liquid whey a mandatory step in WPC production. Hydrogen peroxide (HP) and benzoyl peroxide (BPO) are approved with generally recognized as safe status for use in the production of annatto-colored whey (FDA, 2008). Limited dated information is available on the effect of bleaching on the flavor of dried whey. McDonough et al. (1968) concluded that treatment with either HP or BPO was effective for the bleaching of liquid whey. The group also stated that oxidized flavors found in the liquid whey after bleaching were not present after spray drying. However, descriptive analysis and volatile compound testing were not conducted and only whey powder was evaluated, not WPC. Hydrogen peroxide research relating to whey has been principally concerned with antimicrobial effects and protein functionality (Jasewicz and Porges, 1959; Grindrod and Nickerson, 1967; Cooney and Morr, 1972). Additionally, BPO has been researched primarily relating to its effect on cheese curd (Washam et al., 1974) and its effect on cheese milk (Kuramoto and Jezeski, 1954) rather than its effect on whey. To our knowledge, there are no studies that have documented volatile component or sensory property differences between bleached and unbleached liquid whey or spraydried WPC. The objective of this study was to characterize the effect of bleaching on flavor of liquid whey and spray-dried Cheddar WPC.

\section{MATERIALS AND METHODS}

\section{Experimental Design}

This study was divided into 2 parts. In part 1, the effect of bleaching on flavor and volatile components of Cheddar whey was investigated. Freshly pasteurized, separated liquid whey was subjected to BPO and HP bleaching at 2 concentrations. An unbleached control was also included. In part 2 , the same Cheddar cheese make procedure was then used to produce WPC70 (WPC with $70 \%$ protein) using the highest concentration of each bleaching agent evaluated in part 1, as well as a control, for a total of 3 treatments. In part 1, liquid whey was analyzed by descriptive sensory and instrumental analysis. In part 2, liquid whey, WPC liquid retentate, and WPC were collected for analysis by chemical composition, annatto concentration, color, and descriptive sensory and instrumental analysis.

\section{Liquid Whey Production}

Whole raw bovine milk (approximately $78 \mathrm{~kg}$ ) was received from the North Carolina State University Dairy Education Unit (Raleigh). Milk was heated to $63^{\circ} \mathrm{C}$ and held for 30 min in a pasteurization vat (model MPD1050, Micro Process Design, D \& F Equipment Co, McLeansville, NC). Milk was cooled and refrigerated at $4^{\circ} \mathrm{C}$ overnight for processing the next day. The pasteurized milk was heated to $31^{\circ} \mathrm{C}$ in a $250-\mathrm{kg}$ cheese vat (model MX4, Kusel Equipment Company, Watertown, WI). The milk was inoculated at the rate of $0.041 \mathrm{~g} /$ $\mathrm{kg}$ of milk with a freeze-dried lactic acid starter culture including Lactococcus lactis ssp. lactis and Lactococcus lactis ssp. cremoris (Choozit MA 11, Danisco, New Century, NJ). The milk was agitated and allowed to ripen for $60 \mathrm{~min}$. Double-strength annatto food color (Danisco) was added at the rate of $0.033 \mathrm{~mL} / \mathrm{kg}$ of milk diluted 20 times in deionized water. Calcium chloride solution (50\%, Dairy Connection Inc., Madison, WI) was added at the rate of $0.39 \mathrm{~mL} / \mathrm{kg}$ of milk. The ripened milk, $31^{\circ} \mathrm{C}$, was coagulated with double-strength recombinant rennet (Dairy Connection Inc.) for $30 \mathrm{~min}$ at a rate of $0.09 \mathrm{~mL} / \mathrm{kg}$ of milk diluted 80 times in deionized water. The coagulum was cut with $0.95-\mathrm{cm}$ wire knives and the curd and whey were allowed to rest for $5 \mathrm{~min}$ followed by gentle stirring for $10 \mathrm{~min}$ without added heat. The temperature was increased gradually from 31 to $39^{\circ} \mathrm{C}$ over $30 \mathrm{~min}$. The curd was continuously stirred at $39^{\circ} \mathrm{C}$ until the target whey drain $\mathrm{pH}$ of 6.35 was attained. The whey was then drained, fines were removed, and the whey was immediately pasteurized at $63^{\circ} \mathrm{C}$ for $30 \mathrm{~min}$. The whey was immediately processed with a hot-bowl cream separator (model FJ 125 EAR, Clair, Althofen, Austria) to reduce the fat content. Whey $(12 \mathrm{~L})$ was removed for bleaching trials. Total percentage solids and percentage fat content of fluid milk and whey were analyzed using the Smart System 5 moisture-solids analyzer with SmartTrac rapid fat analysis (CEM, Matthews, NC). Additional percentage solids measurements were also recorded with the CEM apparatus.

Immediately following the production of Cheddar whey, whey was treated with or without bleaching agents. All samples were covered during preparation to minimize light exposure. Benzoyl peroxide powder (97\%, wet with $25 \%$ water, Alfa Aesar, Ward Hill, MA) was tested using 2 concentrations, 10 and $20 \mathrm{mg} / \mathrm{kg}$. Hydrogen peroxide (35\%, VWR International, West Chester, PA) was tested at 2 concentrations, 250 and $500 \mathrm{mg} / \mathrm{kg}$. These concentrations were selected because they represented the legal range of HP for bleaching of whey or the range covering good manufacturing practices for BPO bleaching of whey. Whey was heated to 
$60^{\circ} \mathrm{C}$ for 90 min with the addition of either HP or BPO. An unbleached control sample was heated for the same time and temperature. After $90 \mathrm{~min}$, catalase (Food Pro CAT, Danisco) was added to the HP samples. Inactivation of HP was confirmed when EM Quant peroxide testing strips (EMD Chemicals Inc., Gibbstown, NJ) produced a negative result for the presence of HP. No additional treatment was necessary for the use of BPO. Wheys were cooled to $4^{\circ} \mathrm{C}$ and sensory and instrumental testing commenced immediately. The entire experiment with liquid whey was replicated 2 times.

\section{WPC Production}

Whole raw bovine milk (approximately $193 \mathrm{~kg}$ ) was received from the North Carolina State University Dairy Education Unit (Raleigh). The same cheese make procedure was followed as described previously for liquid whey production. Following bleaching for 60 min at $60^{\circ} \mathrm{C}$ or heat treatment only (control), catalase was added to the HP treatment. Liquid whey was then subjected to UF. Sample treatments were control (no bleaching agent), HP bleaching at $500 \mathrm{mg} / \mathrm{kg}$, and BPO bleaching at $20 \mathrm{mg} / \mathrm{kg}$.

Prior to processing, the cartridge membranes were given a short cleaning cycle. First, the soak solution was flushed out from the system until the flush water was at neutral $\mathrm{pH}$. The membrane was then washed and rinsed in a series of cleaning and sanitizing steps using $0.1 \mathrm{~N}$ sodium hydroxide solution (VWR International) at $50^{\circ} \mathrm{C}$ and deionized water. Clean water flux was determined by operating with an inlet pressure of $69 \mathrm{kPa}$ and retentate outlet pressure of $34.5 \mathrm{kPa}$. The flux (L/ $\mathrm{m}^{2}$ per hour) was calculated based on the weight of permeate collected in $30 \mathrm{~s}$ and the filtration area.

Freshly pasteurized, separated Cheddar whey was weighed, divided into 3 batches (approximately $47 \mathrm{~kg}$ each), and placed in 60-L stainless steel kettles (model 601BP Polar Ware Company, Kiel, WI). Following bleaching or heat treatment (control), liquid wheys were then concentrated using a UF system (model Pellicon 2, Millipore Inc., Billerica, MA) equipped with 2 polyethersulfone cartridge membrane filters (model P2B010V05, nominal separation cutoff $=10,000 \mathrm{kDa}$, surface area $\left.=0.5 \mathrm{~m}^{2}\right)$. A variable speed peristaltic pump (model 77410-10) equipped with model 77601-00 pumpheads with silicone tubing (model 96440-73) was used to circulate the product. Pumps, pumpheads, and tubing were obtained from Cole-Palmer (Vernon Hills, IL). Each sample was run through a separate pumphead and UF assembly. The inlet pressure was $207 \mathrm{kPa}$ and the retentate outlet pressure was $200 \mathrm{kPa}$ with no permeate back pressure on the permeate side. Samples were heated using a circular immersion heater (model
356K05K73, McMaster-Carr, Atlanta, GA). Products were covered with aluminum foil during UF to minimize direct light exposure.

Whey was heated to $60^{\circ} \mathrm{C}$ and processed with the UF system in batch recirculation mode. Trials were performed running the UF apparatus at this temperature and no inconsistencies were detected in the WPC produced or in the integrity of the membranes. When starting the process, approximately $1 \mathrm{~L}$ of liquid was discarded from each of the 3 systems. The permeate was directed to the feed tank and the liquid was circulated for $10 \mathrm{~min}$. The permeate was collected and samples were run for approximately $60 \mathrm{~min}$ or until they reached $8 \%$ solids. Liquid whey $(2 \mathrm{~L})$ was collected for volatile analysis, proximate analysis, and annatto extraction. Protein concentration continued until $22 \%$ solids was reached. The flux was determined by weight every $15 \mathrm{~min}$. The total time of UF was approximately $2.5 \mathrm{~h}$. After UF was complete, the UF retentate left in the feed vat was combined with the UF retentate drained from the dead volume of the UF system for a yield of approximately $1.5 \mathrm{~kg}$. The $\mathrm{WPC}$ retentate $(500 \mathrm{~mL})$ was retained for analysis. The final liquid UF retentate was spray dried.

The 22\% WPC retentate was dried in a spray dryer (model Lab 1, Anhydro Inc., Soeberg, Denmark). A peristaltic pump (model 9154K43, McMaster-Carr) was utilized to feed the spray drier at a feed rate of approximately $1 \mathrm{~kg} / \mathrm{h}$. Retentate feed temperature was $22^{\circ} \mathrm{C}$. The spray drier inlet temperature was $150^{\circ} \mathrm{C}$ and the outlet temperature was $80^{\circ} \mathrm{C}$. The total time of the drying run was approximately $1 \mathrm{~h}$. Powders were transferred to mylar bags (TF-4000, Impak Corp., Central City, SD) and then sealed and cooled by immediately placing in a freezer at $-4^{\circ} \mathrm{C}$. Powders were cooled below $0^{\circ} \mathrm{C}$ in less than $1 \mathrm{~h}$. Production of the liquid whey and all 3 spray-dried WPC treatments from that lot of fresh Cheddar whey was completed in $1 \mathrm{~d}$. This experiment was replicated 3 times.

\section{Annatto Extraction of Whey Products}

A method was adapted from Levy et al. (1997) to extract norbixin, the primary carotenoid compound in water-soluble annatto (Preston and Rickard, 1980), from both liquid and dried whey products. The extraction procedure and measurements were performed with premium full-spectrum F885 flat sheet filters (Ergomart, Dallas, TX) covering all lights to minimize norbixin isomerization and degradation (Mercadante, 2008). Chloroform, ethanol, and water were obtained from EMD Chemicals Inc. Acetic acid was obtained from Mallinckrodt Baker (Phillipsburg, NJ). Liquid whey $(10 \mathrm{~mL})$ was weighed into a $50-\mathrm{mL}$ centrifuge 
tube (Nalgene, Rochester, NY). To this, $6 \mathrm{~mL}$ of ethanol was added, vortexed for $30 \mathrm{~s}$, and allowed to stand for $30 \mathrm{~min}$. Three milliliters of chloroform was added and vortexed with centrifugation at $1,500 \times g$ for 10 min at $4^{\circ} \mathrm{C}$ (model RC5B, Thermo Scientific). The supernatant was removed to a separate centrifuge tube. The remaining solids were centrifuged an additional time at $16,500 \times g$ for $10 \mathrm{~min}$ at $4^{\circ} \mathrm{C}$. Supernatant was removed and combined with other liquid. Two milliliters of acetic acid (1\%) was added to the supernatant, vortexed, and centrifuged at $1,500 \times g$ for $10 \mathrm{~min}$. The bottom chloroform layer containing the norbixin was collected.

For spray-dried whey protein, $1 \mathrm{~g}$ was weighed into a $50-\mathrm{mL}$ centrifuge tube (Nalgene) and $2 \mathrm{~mL}$ of HPLCgrade water was added. This sample was then vortexed for $30 \mathrm{~s}$. To this, $6 \mathrm{~mL}$ of ethanol was added, vortexed for $30 \mathrm{~s}$, and allowed to stand for $30 \mathrm{~min}$. Three milliliters of chloroform was added and vortexed with centrifugation at $16,500 \times g$ for $10 \mathrm{~min}$ at $4^{\circ} \mathrm{C}$ (model RC5B, Thermo Scientific). The supernatant was removed to a separate centrifuge tube. Two milliliters of acetic acid (1\%) was added to the supernatant, vortexed for $30 \mathrm{~s}$, and centrifuged at $16,500 \times g$ for $10 \mathrm{~min}$. The bottom chloroform layer containing the norbixin was collected and the volume was measured.

\section{Solid-Phase Extraction}

Solid-phase extraction (SPE) was applied to the chloroform extract (containing norbixin) for filtration and to purify norbixin (Bareth et al., 2002). The Strata- $\mathrm{NH}_{2} \mathrm{SPE}$ column (500 mg/3 mL, Phenomenex) was conditioned with $7 \mathrm{~mL}$ of $n$-hexane (VWR International). An aliquot of chloroform extract $(1 \mathrm{~mL})$ was transferred onto the SPE column. The column was rinsed with $5 \mathrm{~mL}$ of $n$-hexane:diethyl ether [1:1 ( $\mathrm{vol} /$ vol)] and $1 \mathrm{~mL}$ of acetone (VWR International). The norbixin was eluted with $3 \mathrm{~mL}$ of methanol:glacial acetic acid $[7: 3(\mathrm{vol} / \mathrm{vol})]$. The final volume of eluent was measured. The resulting extract was measured by both spectrophotometry and HPLC.

\section{Spectrophotometry}

Spectrophotometer data was obtained with a UVvisible spectrophotometer (Cary 300 Bio, Varian, Cary, $\mathrm{NC}$ ). A $0.7-\mathrm{mL}$ aliquot of each sample was measured in a 28Q10 Spectrosil quartz cuvette (Starna Cells Inc., Atascadero, CA). A standard curve was created within the concentration range of $50 \mu \mathrm{g} / \mathrm{kg}$ to $3 \mathrm{mg} / \mathrm{kg}$ norbixin. Norbixin powder (45\%, Chr. Hansen, Milwaukee, WI) was rehydrated in $2.5 \%$ potassium hydroxide and then diluted in methanol:glacial acetic acid [7:3 (vol/ vol)]. Carotenoids generally have 3 peaks of absorption maxima (Levy and Rivadeneira, 2000). The maxima used for calculation was $458 \mathrm{~nm}$. The carotenoid concentration of the SPE extract was calculated using the standard curve. Norbixin concentration was calculated by total solids and correction for dilution during the extraction and SPE processes.

\section{HPLC Separation}

High performance liquid chromatography analysis was performed to confirm that the product measured spectrophotometrically was norbixin. The analysis was performed with a TSP SpectraSystem AS3000 Variable Loop Autosampler, a P2000 Binary Gradient Pump, a UV6000LP UV-visible detector with tungsten lamp (all from Thermo Scientific), an HPLC-column Hyperclone ODS $(25 \mathrm{~cm} \times 0.4 \mathrm{~cm}$ i.d. $)$ with 5 - $\mu \mathrm{m}$ packing (Phenomenex), and a solvent mix of acetonitrile-acetic acid (5\%) 75:25 (vol/vol). Isocratic flow was $1 \mathrm{~mL} / \mathrm{min}$, column temperature was $35^{\circ} \mathrm{C}$, detection wavelength was $458 \mathrm{~nm}$, and injection volume was $10 \mu \mathrm{L}$ (Bareth et al., 2002). Acetonitrile was obtained from Acros Organics (Geel, Belgium).

\section{Descriptive Sensory Analysis}

All sensory testing was conducted in accordance with the North Carolina State University Institutional Review Board for Human Subjects guidelines. Evaluation of liquid whey and WPC was conducted by a trained descriptive sensory panel using an established flavor language (Drake et al., 2003, 2009; Wright et al., 2009). Panelists $(\mathrm{n}=10$; 9 females, 1 male; ages $25-45 \mathrm{yr})$ each had more than $150 \mathrm{~h}$ of previous experience with the sensory analysis of whey products using the Spectrum descriptive analysis method (Meilgaard et al., 1999). Liquid whey and reconstituted WPC (10\% solids) were both evaluated by placing $30 \mathrm{~mL}$ of product in 3-digitcoded, 60-mL lidded cups (Solo Cup Company, Champaign, IL). Preparations were conducted with overhead lights off to avoid exposure to light. Liquid whey samples were evaluated immediately after treatment. Whey protein powders were rehydrated [10\% solids (wt/vol)] and evaluated within $7 \mathrm{~d}$ of production. Samples were evaluated in duplicate at room temperature by each panelist using computerized ballots in a randomized order (Compusense five, release 4.8, Compusense Inc., Guelph, Ontario, Canada).

\section{Color Analysis of Powders}

Color of WPC powders was measured using a Minolta Chroma meter (CR-410, Ramsey, NJ). Ten grams 
of WPC was placed in the bottom of a $60 \mathrm{~mm} \times 15$ mm polystyrene Petri dish (Becton Dickinson, Franklin Lakes, NJ) for triplicate measurements. The equipment was calibrated before each session with a factory-supplied calibration plate. The Hunter CIE Lab color scale was used, where $\mathrm{L}^{*}$ is lightness, $\mathrm{a}^{*}$ is redness, and $\mathrm{b}^{*}$ is yellowness.

\section{Solid-Phase Microextraction of Volatile Compounds}

Volatile compounds of liquid whey and WPC were collected using solid-phase microextraction and were separated and identified by GC-MS using a modified method of Wright et al. (2006). Spray-dried powders were reconstituted to $10 \%$ solids with HPLC-grade water. Sodium chloride (VWR International) was added at $10 \%$ (wt/wt) and internal standard solution (2-methyl-3-heptanone) in methanol at $81 \mathrm{mg} /$ $\mathrm{kg}$ added for a final concentration of $81 \mu \mathrm{g} / \mathrm{kg}$. Five grams of sample was placed in 20-mL autosampler vials with steel screw tops containing silicone septa faced in Teflon (Microliter Analytical, Suwanee, FL). Samples were injected using a CombiPal autosampler (CTC Analytics, Zwingen, Switzerland) attached to an Agilent $6890 \mathrm{~N}$ GC with 5973 inert mass selective detector (Agilent Technologies Inc., Cary, NC) equipped with a DB-5 column of $30-\mathrm{m}, 0.25-\mathrm{mm}$ I.D., $0.25-\mu \mathrm{m}$ film thickness (Restek US, Bellefonte, PA). Samples were maintained at $10^{\circ} \mathrm{C}$ before fiber exposure. Samples were equilibrated at $40^{\circ} \mathrm{C}$ for $25 \mathrm{~min}$ before $30 \mathrm{~min}$ fiber exposure of a 1-cm DVB/Carboxen/PDMS Stableflex SPME fiber (Supelco, Bellefonte, PA) at $31 \mathrm{~mm}$ with 4 $\mathrm{s}$ of pulsed agitation at $250 \mathrm{rpm}$. Fibers were inserted into an injector held at $250^{\circ} \mathrm{C}$ for 5 min at a depth of $50 \mathrm{~mm}$. The GC method used an initial temperature of $40^{\circ} \mathrm{C}$ for 3 min with a ramp rate of $5^{\circ} \mathrm{C} / \mathrm{min}$ to $90^{\circ} \mathrm{C}$, followed by a ramp rate of $10^{\circ} \mathrm{C} / \mathrm{min}$ to $200^{\circ} \mathrm{C}$, held for $10 \mathrm{~min}$, and a ramp rate of $20^{\circ} \mathrm{C} / \mathrm{min}$ to $250^{\circ} \mathrm{C}$, held for 5 min. Helium was used as the carrier gas at a constant flow rate of $1 \mathrm{~mL} / \mathrm{min}$. Compounds were identified using the NIST 2005 library of spectra and comparison of spectra with authentic standards. Relative abundance for each compound was calculated using the peak area of the volatile compound and the peak area and known concentration of the internal standard. Retention indices were calculated using an alkane series (Van den Dool and Kratz, 1963). Chemical standards were obtained from Sigma Aldrich (Milwaukee, WI).

\section{Composition}

The samples of liquid whey and liquid WPC retentate were analyzed for total solids and total $\mathrm{N}$ content using forced air oven drying (AOAC, 2000; method
990.20; 33.2.44) and Kjeldahl N (AOAC, 2000; method 991.20; 33.2.11), respectively. The WPC samples were reconstituted to $10 \%$ solids and the rehydrated liquids were analyzed for fat by ether extraction (AOAC, 2000; method 989.05 ; 33.2.26) and total $\mathrm{N}$ by the method indicated above. The WPC powders were analyzed for moisture using vacuum oven drying for $5 \mathrm{~h}$ (Wehr and Frank, 2004; method 15.111).

\section{Statistics}

Proximate analyses, sensory, and instrumental results were analyzed using XLSTAT statistical software (version 2009.1.02, Addinsoft, New York, NY). Oneway ANOVA was conducted to explore the effect of bleaching on color, chemical composition, and descriptive sensory and instrumental analyses. Tukey's least significant difference was conducted as a post hoc test. Principal component analysis using the correlation matrix was also conducted to determine how bleached and unbleached treatments differentiated across sensory and instrumental measurements.

\section{RESULTS}

\section{Experiment 1: Liquid Whey Descriptive Sensory Analysis}

Descriptive sensory analysis of liquid whey differentiated the samples based on treatment. No significant differences $(P<0.05)$ were identified in the sensory attributes of the liquid whey with different HP bleach concentrations (Table 1). The high concentration (20 $\mathrm{mg} / \mathrm{kg}$ ) of BPO resulted in a detectable cardboard flavor but of significantly lower intensity compared with HP samples $(P<0.05)$. Bleaching with HP resulted in liquid whey with higher cardboard and fatty flavors and a loss of sweet aromatic and cooked flavors compared with BPO-bleached whey and the control whey.

\section{Volatile Components Analysis}

Instrumental analysis was performed to relate volatile compounds to sensory attributes perceived in the samples. Compounds were selected for their association with fresh flavors or oxidized flavors, or both, in liquid or spray-dried whey (Quach et al., 1999; Drake et al., 2009; Wright et al., 2009). Liquid whey samples were differentiated by treatment $(P<0.05)$ with no differences $(P>0.05)$ identified between high and low concentrations of each bleaching agent (Table 2), consistent with sensory results. Liquid whey bleached by HP was characterized by higher concentrations of heptanal, hexanal, and octanal compared with control or BPO-bleached whey. 
Table 1. Descriptive sensory analysis means $(n=2)$ of bleached and unbleached Cheddar liquid whey ${ }^{1}$

\begin{tabular}{lccccccc} 
Treatment $^{2}$ & Aroma intensity & Cooked/milky & Cardboard & Fatty & Sweet aromatic & Sweet & Astringency \\
\hline Control & $2.2^{\mathrm{a}}$ & $3.0^{\mathrm{ab}}$ & $\mathrm{ND}^{3}$ & $\mathrm{ND}$ & $1.2^{\mathrm{a}}$ & $2.0^{\mathrm{a}}$ & $1.2^{\mathrm{a}}$ \\
HP 500 & $2.2^{\mathrm{a}}$ & $2.2^{\mathrm{b}}$ & $2.4^{\mathrm{a}}$ & $0.8^{\mathrm{a}}$ & ND & $2.0^{\mathrm{a}}$ & $1.2^{\mathrm{a}}$ \\
HP 250 & $2.1^{\mathrm{a}}$ & $2.2^{\mathrm{b}}$ & $1.8^{\mathrm{a}}$ & $0.8^{\mathrm{a}}$ & $\mathrm{ND}$ & $2.0^{\mathrm{a}}$ & $1.2^{\mathrm{a}}$ \\
BPO 20 & $2.2^{\mathrm{a}}$ & $3.4^{\mathrm{a}}$ & $0.6^{\mathrm{b}}$ & $\mathrm{ND}$ & $1.20^{\mathrm{a}}$ & $2.0^{\mathrm{a}}$ & $1.2^{\mathrm{a}}$ \\
BPO 10 & $2.2^{\mathrm{a}}$ & $3.6^{\mathrm{a}}$ & $\mathrm{ND}$ & $\mathrm{ND}$ & $1.20^{\mathrm{a}}$ & $2.0^{\mathrm{a}}$ & $1.2^{\mathrm{a}}$ \\
\hline
\end{tabular}

${ }^{\mathrm{a}, \mathrm{b}}$ Means in the same column not sharing a common superscript are different $(P<0.05)$.

${ }^{1}$ Intensities were scored on a 0 to 15 -point universal scale where $0=$ no intensity and $15=$ very high intensity (Meilgaard et al., 1999). Liquid whey and whey protein flavor intensities generally fall between 0 and 5 on this scale (Drake et al., 2003, 2009; Carunchia Whetstine et al., 2005; Wright et al., 2009).

${ }^{2} \mathrm{HP}=$ hydrogen peroxide; $\mathrm{BPO}=$ benzoyl peroxide. Numerals indicate bleach concentration: HP treatments $=250,500 \mathrm{mg} / \mathrm{kg} ; \mathrm{BPO}$ treatments $=10,20 \mathrm{mg} / \mathrm{kg}$.

${ }^{3} \mathrm{ND}=$ not detected.

\section{Experiment 2: WPC Annatto Recovery}

Standard curves were constructed using both HPLC and UV-visible spectrophotometry (results not shown). Both methods were sensitive and consistent. The HPLC analysis was utilized as validation of spectrophotometer data and extraction of norbixin. Both methods resulted in a linear response to the lowest concentration tested of $50 \mu \mathrm{g} / \mathrm{kg}$ of norbixin. Based on the results from the developed method of norbixin extraction from whey products, there was no difference in bleaching efficacy $(P<0.05)$ between WPC from whey bleached by HP $(500 \mathrm{mg} / \mathrm{kg})$ and WPC from whey bleached by BPO (20 $\mathrm{mg} / \mathrm{kg}$; Table 3). Results are reported in milligrams per kilogram of solids. Norbixin concentration was lower in HP liquid whey compared with BPO liquid whey (1.14 vs. $2.76 \mathrm{mg} / \mathrm{kg}$ ) and in liquid retentate (2.64 vs. 3.95 $\mathrm{mg} / \mathrm{kg}$ ), but only liquid whey treatments were significantly different $(P<0.05)$. No significant difference $(P$ $<0.05)$ in norbixin concentration was detected between
WPC bleached by either bleaching treatment (Table 3 ; Figure 1).

\section{Descriptive Sensory Analysis}

Sensory analysis of reconstituted WPC with $10 \%$ solids differentiated each of the 3 treatments (Table 4). Similar to the results of liquid whey analysis, the HP-bleached WPC resulted in a loss of sweet aromatic flavor and increased cardboard flavor $(P<0.05)$ compared with BPO and the control. Fatty/oxidized flavor was also characteristic of WPC bleached with HP.

\section{Volatile Components Analysis}

Dried whey samples were differentiated by treatment $(P<0.05$; Table 5$)$. Whey protein concentrate bleached by HP was characterized by secondary lipid oxidation compounds pentanal, hexanal, heptanal, octanal, and nonanal (Figure 2) and concentrations of hexanal, pen-

Table 2. Relative abundance $(\mu \mathrm{g} / \mathrm{kg})$ of selected volatile compounds in bleached and unbleached Cheddar liquid whey

\begin{tabular}{lccccc}
\hline & \multicolumn{5}{c}{ Treatment $^{1}$} \\
\cline { 2 - 5 } Compound & Control & HP 250 & HP 500 & BPO 10 & BPO 20 \\
\hline 2-Octenal & $0.053^{\mathrm{a}}$ & $0.027^{\mathrm{a}}$ & $0.038^{\mathrm{a}}$ & $0.016^{\mathrm{a}}$ & $0.017^{\mathrm{a}}$ \\
2-Pentylfuran & $0.043^{\mathrm{b}}$ & $0.618^{\mathrm{a}}$ & $0.711^{\mathrm{a}}$ & $0.093^{\mathrm{ab}}$ & $0.340^{\mathrm{ab}}$ \\
Acetic acid & $0.076^{\mathrm{a}}$ & $0.095^{\mathrm{a}}$ & $0.154^{\mathrm{a}}$ & $0.091^{\mathrm{a}}$ & $0.035^{\mathrm{a}}$ \\
Benzaldehyde & $0.007^{\mathrm{b}}$ & $0.202^{\mathrm{a}}$ & $0.101^{\mathrm{ab}}$ & $0.001^{\mathrm{b}}$ & $0.002^{\mathrm{b}}$ \\
Butyric acid & $0.111^{\mathrm{a}}$ & $0.064^{\mathrm{a}}$ & $0.103^{\mathrm{a}}$ & $0.045^{\mathrm{a}}$ & $0.025^{\mathrm{a}}$ \\
Diacetyl & $0.763^{\mathrm{a}}$ & $0.135^{\mathrm{b}}$ & $0.111^{\mathrm{b}}$ & $0.481^{\mathrm{ab}}$ & $0.253^{\mathrm{ab}}$ \\
Heptanal & $\mathrm{ND}^{2}$ & $0.151^{\mathrm{a}}$ & $0.197^{\mathrm{a}}$ & $\mathrm{ND}^{\mathrm{b}}$ & $0.015^{\mathrm{b}}$ \\
Hexanal & $0.086^{\mathrm{b}}$ & $9.15^{\mathrm{a}}$ & $10.5^{\mathrm{a}}$ & $0.192^{\mathrm{b}}$ & $1.48^{\mathrm{b}}$ \\
Nonanal & $0.086^{\mathrm{ab}}$ & $0.118^{\mathrm{ab}}$ & $0.147^{\mathrm{a}}$ & $0.024^{\mathrm{b}}$ & $0.032^{\mathrm{b}}$ \\
Octanal & $\mathrm{ND}$ & $0.022^{\mathrm{a}}$ & $0.043^{\mathrm{a}}$ & $\mathrm{ND}$ & $0.005^{\mathrm{b}}$ \\
\hline
\end{tabular}

${ }^{\mathrm{a}, \mathrm{b}}$ Means in the same row not sharing a common superscript are different $(P<0.05)$.

${ }^{1} \mathrm{HP}=$ hydrogen peroxide; $\mathrm{BPO}=$ benzoyl peroxide. Numerals indicate bleach concentration: HP treatments $=250,500 \mathrm{mg} / \mathrm{kg} ; \mathrm{BPO}$ treatments $=10,20 \mathrm{mg} / \mathrm{kg}$.

${ }^{2} \mathrm{ND}=$ not detected. 
Table 3. Norbixin recovery ( $\mathrm{mg}$ of norbixin $/ \mathrm{kg}$ of total solids) from liquid and dry Cheddar whey products

\begin{tabular}{lccc}
\hline & \multicolumn{3}{c}{ Treatment $^{1}$} \\
\cline { 2 - 4 } Whey product (\% solids) & Control & HP & BPO \\
\hline Liquid whey (8\%) & $3.31^{\mathrm{a}}$ & $1.14^{\mathrm{b}}$ & $2.76^{\mathrm{a}}$ \\
WPC $^{2}$ retentate $(22 \%)$ & $7.97^{\mathrm{a}}$ & $2.64^{\mathrm{b}}$ & $3.95^{\mathrm{b}}$ \\
WPC $(97 \%)$ & $10.0^{\mathrm{a}}$ & $6.28^{\mathrm{b}}$ & $5.73^{\mathrm{b}}$ \\
\hline
\end{tabular}

${ }^{\mathrm{a}, \mathrm{b}}$ Means in the same row not sharing a common superscript are different $(P<0.05)$.

${ }^{1} \mathrm{HP}=$ hydrogen peroxide; $\mathrm{BPO}=$ benzoyl peroxide.

${ }^{2} \mathrm{WPC}=$ whey protein concentrate.

tanal, heptanal, and octanal were higher in HP-bleached WPC compared with BPO-bleached WPC or control WPC (Table 5). Hexanal was the primary compound of difference between WPC samples. Concentrations of hexanal in HP-bleached WPC were 10-fold higher than the concentrations in other treatments.

\section{Color and Compositional Analysis}

By the Hunter $\mathrm{L}^{*} \mathrm{a}^{*} \mathrm{~b}^{*}$ color scale, the whey powders were differentiated by treatment $(P<0.05)$ on all 3 axes (Table 6 ) and were visually distinguishable. A positive value along the $\mathrm{b}^{*}$ axis represents a more yellow color. A higher value along the $\mathrm{L}^{*}$ axis represents a more white color. A more yellow and less white color was expected in the control sample because it was not bleached. Whey protein concentrates were also differentiated $(P<0.05)$ by bleaching agent. Bleaching by $\mathrm{HP}$ resulted in a powder that was whiter and more yellow compared with the BPO-bleached WPC. Whey protein concentrate samples were not differentiated $(P$ $<0.05)$ by treatment for moisture, fat, $\mathrm{pH}$, or total $\mathrm{N}$ (Table 7).

\section{DISCUSSION}

\section{Experiment 1: Liquid Whey}

In experiment 1 , no significant differences $(P<$ $0.05)$ in sensory attributes or volatile compounds were

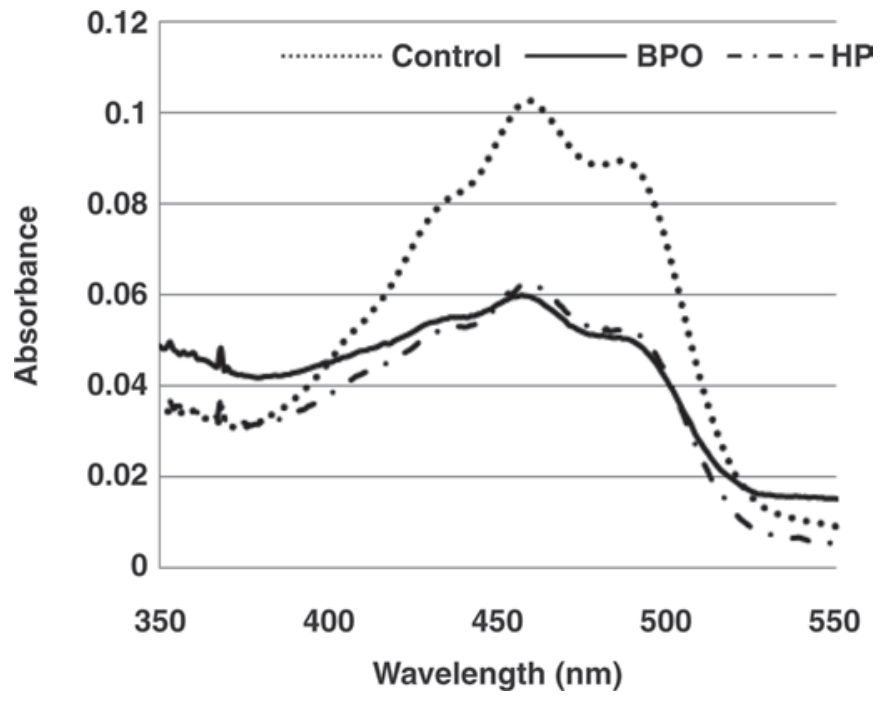

Figure 1. Typical UV-visible spectrophotometer readings of bleached and unbleached Cheddar whey protein concentrate (HP = hydrogen peroxide, bleach concentration of $500 \mathrm{mg} / \mathrm{kg}$; $\mathrm{BPO}=$ benzoyl peroxide, bleach concentration of $20 \mathrm{mg} / \mathrm{kg}$ ).

identified between the whey treated with $500 \mathrm{mg} / \mathrm{kg}$ $\mathrm{HP}$ and the whey treated with $250 \mathrm{mg} / \mathrm{kg} \mathrm{HP}$. Additionally, only cardboard flavor was higher $(P<0.05)$ in the $20 \mathrm{mg} / \mathrm{kg} \mathrm{BPO}$ treatment compared with the $10 \mathrm{mg} / \mathrm{kg}$ treatment. Results from experiment $1 \mathrm{dem}-$ onstrated that off-flavors in liquid whey subjected to bleaching were identified by sensory and instrumental analysis. Previous research also concluded that bleaching negatively affected the flavor of liquid whey (McDonough et al., 1968). Both sensory and instrumental data suggested that the difference in concentration of each bleaching agent did not greatly affect flavor under the bleaching time and temperature profile used. For this reason and to utilize a complete block design with all treatments manufactured from 1 lot of whey within $1 \mathrm{~d}, 1$ concentration each of HP and BPO was used for WPC production along with an unbleached control.

Table 4. Descriptive sensory analysis means $(\mathrm{n}=3)$ of bleached and unbleached rehydrated Cheddar whey protein concentrate

\begin{tabular}{|c|c|c|c|c|c|c|}
\hline Treatment $^{2}$ & $\begin{array}{c}\text { Aroma } \\
\text { intensity }\end{array}$ & Cooked/milky & $\begin{array}{c}\text { Sweet } \\
\text { aromatic }\end{array}$ & Cardboard & Fatty/oxidized & Metallic \\
\hline Control & $2.6^{\mathrm{a}}$ & $2.3^{\mathrm{a}}$ & $0.9^{\mathrm{a}}$ & $1.0^{\mathrm{b}}$ & $\mathrm{ND}^{3}$ & $1.2^{\mathrm{a}}$ \\
\hline HP & $2.2^{\mathrm{ab}}$ & $1.5^{\mathrm{a}}$ & ND & $1.8^{\mathrm{a}}$ & $1.92^{\mathrm{a}}$ & $1.1^{\mathrm{a}}$ \\
\hline $\mathrm{BPO}$ & $2.0^{\mathrm{b}}$ & $1.8^{\mathrm{a}}$ & $1.0^{\mathrm{a}}$ & $0.9^{\mathrm{b}}$ & ND & $0.7^{\mathrm{a}}$ \\
\hline
\end{tabular}

${ }^{\mathrm{a}, \mathrm{b}}$ Means in the same column not sharing a common superscript are different $(P<0.05)$.

${ }^{1}$ Intensities were scored on a 0 to 15 -point universal scale where $0=$ no intensity and $15=$ very high intensity (Meilgaard et al., 1999). Dried whey ingredient intensities generally fall between 0 and 5 on this scale (Drake et al., 2003, 2009; Carunchia Whetstine et al., 2005; Wright et al., 2009).

${ }^{2} \mathrm{HP}=$ hydrogen peroxide; $\mathrm{BPO}=$ benzoyl peroxide.

${ }^{3} \mathrm{ND}=$ not detected. 


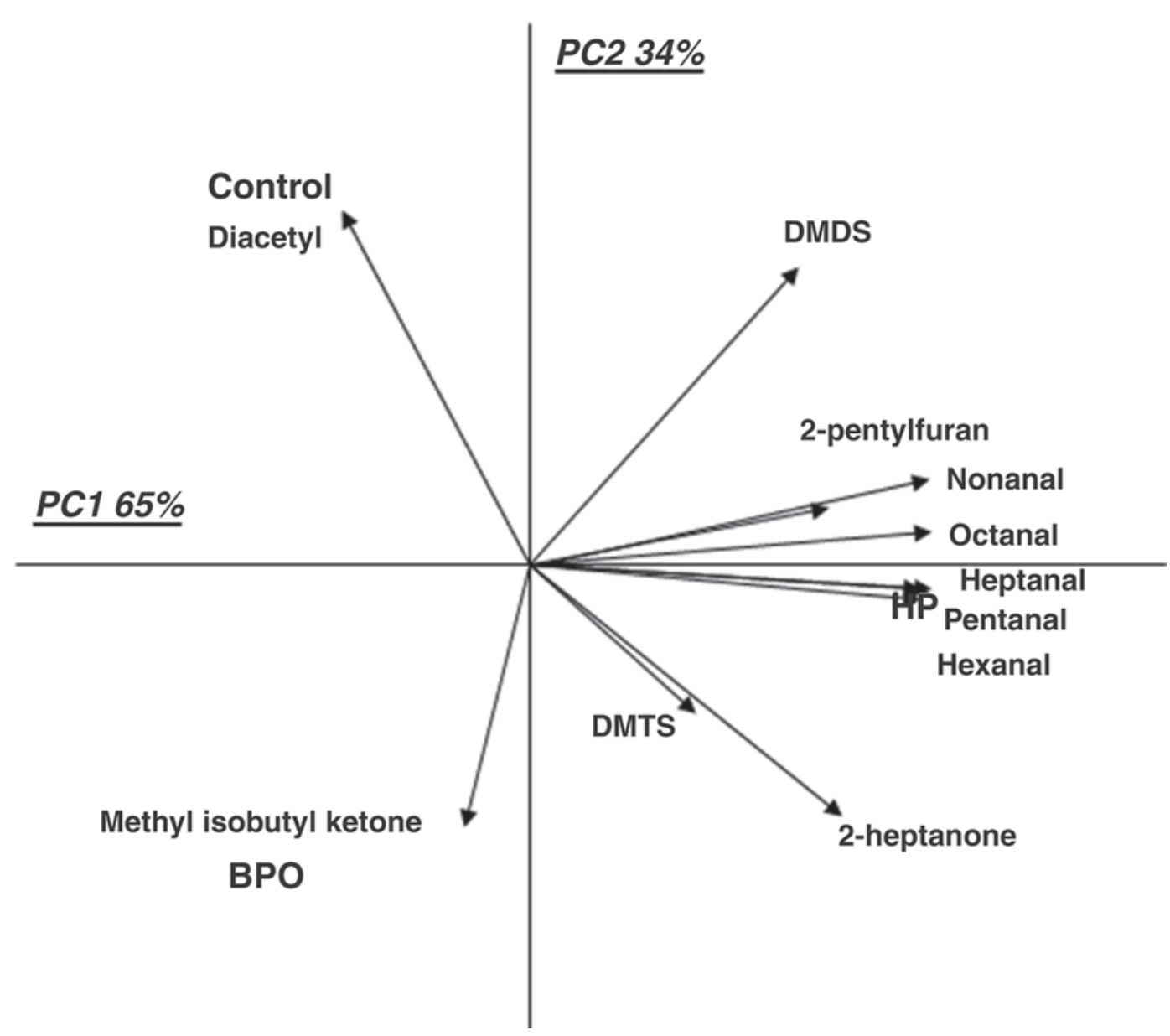

Figure 2. Principal component (PC) biplot of volatile compounds extracted from bleached and unbleached Cheddar whey protein concentrate by solid-phase microextraction $($ control $=$ no bleaching agent; $\mathrm{HP}=$ hydrogen peroxide, bleach concentration of $500 \mathrm{mg} / \mathrm{kg} ; \mathrm{BPO}=$ benzoyl peroxide, bleach concentration of $20 \mathrm{mg} / \mathrm{kg}$ ). DMDS = dimethyl disulfide; DMTS = dimethyl trisulfide.

\section{Experiment 2: WPC Annatto Recovery}

The focus of this study was not to develop whey bleaching conditions for HP and BPO but rather to evaluate their effect on the flavor of WPC. Proof of bleaching activity was required to complete this objective. A method of measurement of annatto in dry whey has been reported (Hammond et al., 1975); however, this method was not reproducible on WPC or liquid whey when tested. During UF, lactose and minerals are removed with water as permeate while whey protein is retained. As the percentage solids increased during UF of liquid whey, the protein concentration increased. Norbixin may be bound to protein (Levy and Rivadeneira, 2000; Emerton, 2008), so an increase in protein concentration was expected to yield an increase in norbixin concentration. The bleaching efficacy of the HP and BPO treatments in WPC when compared with the differences in liquid whey as measured by norbixin recovery suggested that $\mathrm{BPO}$ may require longer exposure times to yield equivalent bleaching in whey. Preliminary studies with commercially manufactured bleached Cheddar WPC34, WPC80, and WPI yielded norbixin values of $1.73 \mathrm{mg} / \mathrm{kg} \pm 0.17,3.04 \mathrm{mg} / \mathrm{kg} \pm$ 0.28 , and $1.08 \mathrm{mg} / \mathrm{kg} \pm 0.40$, respectively; this is within the range of the values we report in the current experiment considering that we added a high concentration of annatto to our cheesemilk and that there is a large acceptable range of annatto addition to cheesemilk. To our knowledge, there are no published studies that report norbixin concentrations in whey protein powders.

Scarce information is available on specific whey processing parameters. Bleaching parameters utilized in this experiment were defined by industry collaboration and analysis of available information on whey processing, legal allowed concentrations and time temperature profiles for whey bleaching (Code of Federal Regulations, 2007a,b), and previous dated studies (McDonough et al., 1968). The exact parameters for liquid whey bleaching are difficult to assess because of 
Table 5. Relative abundance $(\mu \mathrm{g} / \mathrm{kg})$ of selected volatile compounds in bleached and unbleached Cheddar whey protein concentrate

\begin{tabular}{lccl}
\hline & \multicolumn{2}{c}{ Treatment $^{1}$} \\
\cline { 2 - 4 } Compound & Control & HP & BPO \\
\hline 2-Heptanone & $0.959^{\mathrm{a}}$ & $1.20^{\mathrm{a}}$ & $0.363^{\mathrm{a}}$ \\
2-Pentylfuran & $0.161^{\mathrm{b}}$ & $0.886^{\mathrm{a}}$ & $0.094^{\mathrm{b}}$ \\
Diacetyl & $0.391^{\mathrm{a}}$ & $0.125^{\mathrm{b}}$ & $0.143^{\mathrm{b}}$ \\
Dimethyl disulfide (DMDS) & $2.14^{\mathrm{a}}$ & $2.51^{\mathrm{a}}$ & $0.203^{\mathrm{a}}$ \\
Dimethyl trisulfide (DMTS) & $\mathrm{ND}^{2}$ & 0.051 & $\mathrm{ND}^{\mathrm{a}}$ \\
Methyl isobutyl ketone & $1.78^{\mathrm{a}}$ & $2.13^{\mathrm{a}}$ & $2.78^{\mathrm{a}}$ \\
Heptanal & $0.582^{\mathrm{b}}$ & $3.94^{\mathrm{a}}$ & $0.400^{\mathrm{b}}$ \\
Hexanal & $4.62^{\mathrm{b}}$ & $57.1^{\mathrm{a}}$ & $3.93^{\mathrm{b}}$ \\
Nonanal & $0.203^{\mathrm{a}}$ & $0.541^{\mathrm{a}}$ & $0.120^{\mathrm{a}}$ \\
Octanal & $0.151^{\mathrm{b}}$ & $0.908^{\mathrm{a}}$ & $0.026^{\mathrm{b}}$ \\
Pentanal & $\mathrm{ND}$ & $2.50^{\mathrm{a}}$ & $\mathrm{ND}^{\mathrm{b}}$ \\
\hline
\end{tabular}

${ }^{\mathrm{a}, \mathrm{b}}$ Means in the same row not sharing a common superscript are different $(P<0.05)$.

${ }^{1} \mathrm{HP}=$ hydrogen peroxide; $\mathrm{BPO}=$ benzoyl peroxide.

${ }^{2} \mathrm{ND}=$ not detected.

the lack of disclosure of methods by the dairy industry and the large variability within whey processing facilities and among processing companies, including protein concentration methods and apparatus, bleaching agent, bleaching time and temperature profiles, bleaching agent concentration, and overall processing timeframes. Future studies should quantitatively assess and compare efficacy of bleaching concentrations and time and temperature parameters and their effect on WPC flavor and functionality. However, the extraction procedure for annatto presented in this study demonstrates the efficacy of monitoring annatto (specifically norbixin) concentrations in liquid whey products regardless of specific processing parameters and provides an essential tool.

\section{Sensory and Volatile Components Analysis}

Volatile compound and sensory results indicated differences between WPC from different bleaching treatments and the control. Contrary to the conclusions of McDonough et al. (1968), flavors relating to bleaching and type of bleach were also identified in WPC. In the previous study, the authors used bleach concentrations similar to those in our study (10 and $20 \mathrm{mg} / \mathrm{kg}$ of BPO; 300 and $500 \mathrm{mg} / \mathrm{kg}$ of $\mathrm{HP}$ ) and comparable time and temperature parameters $\left(63^{\circ} \mathrm{C}, 1 \mathrm{~h}\right)$. However, they produced only dried whey powder without protein concentration and did not conduct descriptive sensory analysis or volatile compound analysis. Previous studies have suggested that lipid oxidation products can bind to proteins and as such, off-flavors not detected in whey powder may be further concentrated and subsequently detected with increasing protein concentration (Bangs and Reineccius, 1981). It is also possible that the lack of modern mainstream analytical sensory analysis techniques (e.g., no trained sensory panel but qualitative observations) resulted in a lack of documentation of bleaching-associated flavors reported by McDonough et al. (1968). Benzoyl peroxide treatment of milk and cream in excess of $0.0009 \%$ (9 mg/ $\mathrm{kg}$ ) resulted in oxidized flavors detected by experienced dairy judges (Kuramoto and Jezeski, 1954). Mortenson et al. (2008) recently reported that processing effects, including bleaching, did not contribute to differences in sensory profiles and volatile compounds of WPC34 and WPI. However, it is invalid to compare the effect of bleaching when the remaining processing parameters are not held constant between samples. Commercially produced, unbleached ion-exchange whey powders were compared with bleached, membrane-filtered whey powders produced in a pilot plant. The effects of varied processing parameters (i.e., different processing facilities and equipment) on the sensory and volatile profiles of liquid whey and WPC and WPI have been well documented (Carunchia Whetstine et al., 2005; Drake et al., 2009; Evans et al., 2009). Numerous sources of process variability and lack of extensive sensory training may have confounded their ability to discern specific differ-

Table 6. Mean $(\mathrm{n}=3)$ Hunter $\mathrm{L}^{*}, \mathrm{a}^{*}, \mathrm{~b}^{*}$ color values of bleached and unbleached Cheddar whey protein concentrate

\begin{tabular}{lccc}
\hline & \multicolumn{3}{c}{ Color value } \\
\cline { 2 - 4 } Treatment $^{1}$ & $\mathrm{~L}^{*}$ & \multicolumn{1}{c}{$\mathrm{a}^{*}$} & $\mathrm{~b}^{*}$ \\
\hline Control & $86.4^{\mathrm{c}}$ & $0.18^{\mathrm{a}}$ & $15.0^{\mathrm{a}}$ \\
HP & $90.1^{\mathrm{a}}$ & $-0.41^{\mathrm{b}}$ & $13.6^{\mathrm{b}}$ \\
BPO & $89.0^{\mathrm{b}}$ & $-0.61^{\mathrm{c}}$ & $13.5^{\mathrm{c}}$ \\
\hline
\end{tabular}

${ }^{\mathrm{a}-\mathrm{c}}$ Means in the same column not sharing a common superscript are different $(P<0.05)$.

${ }^{1} \mathrm{HP}=$ hydrogen peroxide; $\mathrm{BPO}=$ benzoyl peroxide. 
Table 7. Mean ( $\mathrm{n}=3$ ) composition (\% by weight) of spray-dried Cheddar whey protein concentrate calculated on a dry basis and $\mathrm{pH}$

\begin{tabular}{lcccc}
\hline Treatment $^{1}$ & Fat & Total N & Moisture & $\mathrm{pH}^{2}$ \\
\hline Control & 5.41 & 70.3 & 3.26 & 6.44 \\
HP & 4.08 & 70.7 & 3.07 & 6.48 \\
BPO & 4.17 & 69.4 & 2.70 & 6.47 \\
\hline
\end{tabular}

${ }^{1} \mathrm{HP}=$ hydrogen peroxide; $\mathrm{BPO}=$ benzoyl peroxide.

${ }^{2} \mathrm{pH}$ was measured at $10 \%$ (wt/vol) in deionized water.

ences. Bleach concentrations and conditions were also not disclosed.

Results from the current study demonstrated that flavors differentiating the bleaching treatments in liquid whey do, in fact, carry through to the whey protein powders. In liquid whey, the variability among bleached and unbleached WPC volatile profiles can be attributed to diacetyl and the aldehydes hexanal, heptanal, and octanal (Table 2). Similar results were found in WPC, with pentanal also being recovered (Table 5). These aldehydes have repeatedly been identified in WPC and WPI as primary compounds influencing flavor (Quach et al., 1999; Mahajan et al., 2004; Carunchia Whetstine et al., 2005; Wright et al., 2009). Hexanal, nonanal, and other aldehydes have been associated with fatty flavors or cardboard flavors, or both, in WPC (Drake et al., 2009; Wright et al., 2009). Volatile oxidation products attributed to whey flavor have been linked to agglomeration and storage (Wright et al., 2009), milk source (Carunchia Whetstine et al., 2003), starter culture (Tomaino et al., 2004), cheese type (GallardoEscamilla et al., 2005), and now bleaching. Hundreds of volatile compounds, including aldehydes, may be produced by the oxidation of lipids and the subsequent decomposition of hydroperoxides. When comparing volatile results to descriptive sensory analysis, these increased aldehyde concentrations may explain the increased fatty and cardboard flavors in bleached WPC compared with control WPC. The compounds 2-pentylfuran, 2-octenal, and 2-heptanone are also products of lipid oxidation (Frankel, 1998). Dimethyl disulfide and dimethyl trisulfide are commonly identified in whey proteins, resulting from nonenzymatic browning reactions or protein oxidation (Damodaran, 2008; Wright et al., 2009). These 2 compounds may also be products of the processing conditions (i.e., time and temperature) rather than products of the bleaching step. Because the WPC70 samples were still fresh at the time of analysis, very low concentrations of all volatile compounds were detected. Therefore, further oxidation products may be present at subsequent storage time points.

Hydrogen peroxide may produce the free radicals . $\mathrm{OOH}$ and $\cdot \mathrm{OH}$ by reaction with UV light or transition metals present in milk. The hydroxyl radical $(\cdot \mathrm{OH})$ is the most reactive radical known (McClements and Decker, 2008). Benzoyl peroxide produces benzoyl radicals by homolytic cleavage of an oxygen-oxygen bond, ultimately yielding 2 benzoic acid molecules. Peroxides initiate oxidation by abstracting a hydrogen from a molecule such as a lipid or carotenoid, resulting in the formation of an alkyl radical ( $\mathrm{L} \cdot)$. The alkyl radical reacts with oxygen to form a peroxyl radical (LOO·), which then propagates oxidation by removing hydrogen from another molecule. The hydroperoxide (LOOH) formed may decompose by heat, reaction with UV and visible light, or reaction with transition metals. Hydroperoxide decomposition generally leads to the $\beta$-scission reaction and formation of volatile oxidation products. The alkoxyl radical cleaves an adjacent carbon-carbon bond to form an aldehyde and a radical.

Carotenoids may slow lipid oxidation by reacting faster with free radicals than unsaturated fatty acids, leading to the formation of free radicals with considerably less energy than peroxide radicals. Norbixin lacks the ring structure of other carotenoids such as $\alpha$-tocopherol and maintains a lesser ability to stabilize free radicals. Norbixin in liquid whey is bleached by reaction with free radicals and oxidation of its conjugated double-bond structure, resulting in loss of color, and may undergo further decomposition resulting in products including aldehydes and ketones. The presence of significantly higher levels of aldehydes, coupled with the whiter color produced by HP-bleaching compared with BPO-bleaching, suggests that HP is a more active oxidation initiator than BPO in liquid whey. Both treatments resulted in equivalent bleaching of annatto. The higher activity of the hydroxyl radical and the tendency to react immediately may account for greater hexanal concentrations in HP-bleached WPC compared with control and BPO-bleached WPC.

\section{CONCLUSIONS}

Prior to this research, there was no qualitative and quantitative research evaluating the effects of bleaching and comparison of bleaching agents on the flavor of liquid whey and its carry-through to a spray-dried protein powder. A method was established to quantify norbixin concentration in liquid and dried products. There were significant differences in color of WPC across bleaching treatments; however, the norbixin concentrations were not different. Bleaching of liquid whey does affect WPC flavor, and choice of bleaching agent may also affect flavor. Results of sensory and instrumental analysis of liquid whey and WPC demonstrate that the flavor of liquid whey is representative of the flavor of WPC. The data presented and the method developed will facilitate the research of alternative methods to current 
bleaching processes by making available the option for the evaluation of liquid whey rather than the logistically difficult and time-consuming process of producing WPC for evaluation.

\section{ACKNOWLEDGMENTS}

This is paper FSR-25 09 of the journal series of the Department of Food, Bioprocessing, and Nutritional Sciences, North Carolina State University (Raleigh). The use of trade names does not imply endorsement nor criticisms of those not mentioned. Funding provided in part by Dairy Management Inc. (Rosemont, IL). Special thanks are extended to David Barbano (Cornell University, Ithaca, NY) for his advice and assistance with the proximate analyses and to G. Keith Harris (North Carolina State University) for his assistance with carotenoid extraction methodology.

\section{REFERENCES}

American Dairy Products Institute. 2008. 2008 Dairy Products Utilization and Production Trends. ADPI, Elmhurst, IL.

Association of Official Analytical Chemists. 2000. Official Methods of Analysis. 17th ed. AOAC, Gaithersburg, MD.

Bangs, W. E., and G. A. Reineccius. 1981. Influence of dryer infeed matrices on the retention of volatile flavor compounds during spray drying. J. Food Sci. 47:254-259.

Bareth, A., W. Strohmar, and E. Kitzelmann. 2002. HPLC and spectrophotometric determination of annatto in cheese. Eur. Food Res. Technol. 215:359-364.

Carunchia Whetstine, M. E., A. E. Croissant, and M. A. Drake. 2005. Characterization of dried whey protein concentrate and isolate flavor. J. Dairy Sci. 88:3826-3839.

Carunchia Whetstine, M. E., J. Parker, M. A. Drake, and D. K. Larick. 2003. Determining flavor and flavor variability in commercially produced liquid Cheddar whey. J. Dairy Sci. 86:439-448.

Code of Federal Regulations. 2007a. Benzoyl peroxide (21CFR184. 1157). Page 489 in Code of Federal Regulations, Title 21, Vol. 3. U.S. Government Printing Office, Washington, D.C.

Code of Federal Regulations. 2007b. Hydrogen peroxide (21CFR184.1366). Pages 508-509 in Code of Federal Regulations, Title 21. Vol. 3. U.S. Government Printing Office, Washington, D.C.

Childs, J. L., M. D. Yates, and M. A. Drake. 2007. Sensory properties of meal replacement bars and beverages made from soy and whey proteins. J. Food Sci. 72:425-434.

Cooney, C. M., and C. V. Morr. 1972. Hydrogen peroxide alteration of whey proteins in whey and concentrated whey systems. J. Dairy Sci. 55:567-573.

Damodaran, S. 2008. Amino acids, peptides, and proteins. Pages 217329 in Fennema's Food Chemistry. 4th ed. S. Damodaran, K. L. Parkin, and O. R. Fennema, ed. CRC Press, Boca Raton, FL.

Drake, M. A., Y. Karagul-Yuceer, K. R. Cadwallader, G. V. Civille, and P. S. Tong. 2003. Determination of the sensory attributes of dried milk powders and dairy ingredients. J. Sens. Stud. 18:199216.

Drake, M. A., R. E. Miracle, and J. M. Wright. 2009. Sensory properties of dairy proteins. Pages 429-448 in Milk Proteins: From Expression to Food. Elsevier. New York, NY.

Emerton, V. 2008. Food Colours. Wiley Blackwell Publishing, Oxford, UK.

Evans, J. P., J. Zulewska, M. Newbold, M. A. Drake, and D. M. Barbano. 2009. Comparison of the composition, sensory, and volatile components of $34 \%$ whey and serum protein concentrates. J. Dairy Sci. 92:4773-4791.
FDA. 2008. Direct food substances affirmed as generally recognized as safe. Pages 482-582 in Code of Federal Regulations, Title 21, Part 184. U.S. Government Printing Office, Washington, D.C.

Frankel, E. N. 1998. Hydroperoxide decomposition. Pages 55-77 in Lipid Oxidation. The Oily Press, Bridgwater, UK.

Gallardo-Escamilla, F. J., A. L. Kelly, and C. M. Delahunty. 2005. Sensory characteristics and related volatile flavor compound profiles of different types of whey. J. Dairy Sci. 88:2689-2699.

Grindrod, J., and T. A. Nickerson. 1967. Changes in milk proteins treated with hydrogen peroxide. J. Dairy Sci. 50:142-146.

Hammond, E. G., J. Chang, and G. W. Reinbold. 1975. Colorimetric method for residual annatto in dry whey. J. Dairy Sci. 58:13651366.

International Dairy Foods Association. 2008. Dairy Facts. IDFA, Washington, D.C.

Jasewicz, L., and N. Porges. 1959. Whey preservation by hydrogen peroxide. J. Dairy Sci. 42:1119-1125.

Kuramoto, S., and J. J. Jezeski. 1954. Some factors affecting the action of benzoyl peroxide in the bleaching of milk and cream for blue cheese manufacture. J. Dairy Sci. 37:1241-1246.

Levy, L. W., E. Regalado, S. Navarrete, and R. H. Watkins. 1997. Bixin and norbixin in human plasma: Determination and study of the absorption of a single dose of annatto food color. Analyst (Lond.) 122:977-980.

Levy, W. J., and D. M. Rivadeneira. 2000. Annatto. Pages 115-152 in Natural Food Colorants: Science and Technology. G. J. Lauro and F. J. Francis, ed. Marcel Dekker, New York, NY.

Mahajan, S. S., L. Goddik, and M. C. Qian. 2004. Aroma compounds in sweet whey powder. J. Dairy Sci. 87:4057-4063.

McClements, D. J., and E. A. Decker. 2008. Lipids. Pages 155-216 in Fennema's Food Chemistry. 4th ed. S. Damodaran, K. L. Parkin, and O. R. Fennema, ed. CRC Press, Boca Raton, FL.

McDonough, F. E., R. E. Hargrove, and R. P. Tittsler. 1968. Decolorization of annatto in Cheddar cheese whey. J. Dairy Sci. 51:471-472.

Meilgaard, M. M., G. V. Civille, and T. Carr. 1999. Sensory Evaluation Techniques. 3rd ed. CRC Press, New York, NY.

Mercadante, A. Z. 2008. Analysis of carotenoids. Pages 447-478 in Food Colorants: Chemical and Functional Properties. C. Socaciu, ed. CRC Press, Boca Raton, FL.

Morr, C. V., and E. A. Foegeding. 1990. Composition and functionality of commercial whey and milk protein concentrates and isolate: A status report. Food Technol. 44:100-112.

Morr, C. V., and E. Y. W. Ha. 1991. Off-flavors of whey protein concentrates: A literature review. Int. Dairy J. 1:1-11.

Mortenson, F. E., Z. M. Vickers, and G. A. Reineccius. 2008. Flavor of whey protein concentrates and isolates. Int. Dairy J. 18:649-657.

Preston, H. D., and M. D. Rickard. 1980. Extraction and chemistry of annatto. Food Chem. 5:47-56.

Quach, M. L., X. D. Chen, and R. J. Stevenson. 1999. Headspace sampling of whey protein concentrate solutions using solid-phase microextraction. Food Res. Int. 31:371-379.

Tomaino, R. M., L. G. Turner, and D. K. Larick. 2004. The effect of Lactococcus lactis starter cultures on the oxidative stability of liquid whey. J. Dairy Sci. 87:300-307.

Van den Dool, H., and P. Kratz. 1963. A generalization of the retention index system including linear programmed gas liquid partition chromatography. J. Chromatogr. A 11:463-471.

Washam, C. J., G. W. Reinbold, and E. R. Vedamuthu. 1974. Changes in milk, whey, and bleu cheese as induced by benzoyl peroxide. J. Milk Food Technol. 37:244-249.

Wehr, M. H., and J. F. Frank. 2004. Standard Methods for the Examination of Dairy Products. 17th ed. Am. Publ. Health Assoc. Inc., Washington, D.C

Wright, B. J., S. E. Zevchak, J. M. Wright, and M. A. Drake. 2009. The impact of agglomeration and storage on flavor and flavor stability of whey protein concentrate 80 and whey protein isolate. J. Food Sci. 74:S17-S29.

Wright, J. W., M. E. Carunchia Whetstine, R. E. Miracle, and M. A. Drake. 2006. Characterization of cabbage off-flavor in whey protein isolate. J. Food Sci. 71:C86-C90. 